NBER WORKING PAPER SERIES

\title{
IMPERFECT INFORMATION, CREDIT MARKETS AND UNEMPLOYMENT
}

\author{
Bruce C. Greenwald \\ Joseph E. Stiglitz
}

Working Paper No. 2093

\section{NATIONAL BUREAU OF ECONOMIC RESEARCH 1050 Massachusetts Avenue Cambridge, MA 02138 \\ December 1986}

Invited paper presented at the European Economic Association Meetings, Vienna, Austria, August 28-31, 1986. The research reported here is part of the NBER's research programs in Economic Fluctuations and Labor Studies. Any opinions expressed are those of the authors and not those of the National Bureau of Economic Research. 
NBER Working Paper \#2093

December 1986

Imperfect Information, Credit Markets and Unemployment

\section{ABSTRACT}

This paper describes how imperfect information in both capital and labor markets can, in a context of maximizing firms and perfectly flexible prices and wages, give rise to cyclical variations in unemployment whose character closely resembles that of observed business cycles.

Bruce C. Greenwald Be 11 Communications Research Morristown, NJ 07960
Joseph E. Stiglitz

Princeton University

Princeton, NJ 08544 
The central problem of macro-economics is to explain the level and variability of unemployment. Over the past decade, a consensus has developed that Keynesian explanations are, at best, incomplete, at worst, misleading. It is commonly viewed that Keynes' central assumption was the rigidity of money wages, for which no adequate theoretical justification was provided. In fact, money wages are not rigid -they fell by a third in the Great Depression, and there were wage cuts in many industries in the early $80^{\prime}$ 's. Moreover, unemployment is observed in inflationary economies -- where the constraint on wages not falling is presumably not binding -- and indeed, there is little convincing evidence that industries with greater wage and price flexibility (such as construction) exhibit less variability in employment. ${ }^{1}$

A consensus has not developed, however, on an alternative explanation -- but perhaps that is because unemployment is a complex phenomena, and no single theory will explain all of its facets. We present here a new theory, based on informational imperfections in the capital market. We show how this theory, when accompanied by efficiency wage models (based in part on informational problems within the labor market) can go a long way towards providing a theoretical justification for a number of heretofore unexplained aspects of unemployment. ${ }^{2}$

\section{What Is To Be Explained}

A theory of unemployment must be able to explain the level, variability, form (that is temporary lay-offs vs. reduced hours), and pattern of unemployment (both across sectors and types of individuals). ${ }^{3}$ For instance, in the presence of wage and price rigidities, if the economy is constrained, variations in employment entail the existence of exogenous, unexplained shocks to the marginal product of labor. ${ }^{4}$ It is hard to identify changes in technology which are sufficiently large to account for the observed variability in employment, and neoclassical theories of consumption and investment suggest there are strong economic forces that ought to smooth out demand fluctuations. We shall show that informational imperfections provide a set of explanations for both the nature and apparent magnitudes of these shocks, as well as of the pattern, level, and form of unemployment.

Unemployment, like cancer, is not a single disease, but an assortment of maladies. The nature of unemployment (and its variability) differs in the primary as opposed to secondary sectors. Primary sector jobs typically involve substantial job-related training, large potential variation in individual job performance, and hence a demand for relatively high quality workers, long term career relationships between workers and firms, and relatively high wages. Secondary sector jobs in contrast are associated with little 
training, high turnover, and relatively low wages. Not surprisingly, then, the variability in unemployment in these two sectors differs. Given these differences, which are presumably rooted in the technologies of the jobs in question, the determinants of both levels and variations in unemployment in the two sectors are likely to be different. We argue that although informational imperfections provide explanations for unemployment in both sectors, the models and factors involved will naturally differ between sectors.

\section{Explanation of Variations in the Demand for Labor}

One central function of capital markets is to distribute the risks associated with any particular enterprise among a large number of highly diversified investors. The most familiar vehicle for doing this is the sale of common stock. However, as in the case of most other insurance markets (health, life, etc.), informational imperfections (e.g. moral hazard, adverse selection) will interfere with the operation of these financial mechanisms. ${ }^{5}$ For example, if a company's management with superior "inside" information about the company's likely future prospects is willing to sell common stock to relatively less well-informed "outside" investors at the current market price, then one obvious inference is that this market price does not undervalue and probably overvalues the company. As a result, financial markets should (and do) react to stock issue announcements by lowering the common stock prices of the companies in question. This, in turn, will inhibit the issue of equity and company managements will be forced to seek other means of insuring against the risks associated with their operations. ${ }^{\circ}$ Whether for this or other reasons, the assumption of limited equity markets appears to provide a good working hypothesis for most countries at most times.

Accumulation of "equity" over time by retained earnings is one means of accommodating these risks in the longer run. However, in the short run, restrictions in the level of company operations may be the only way of doing so. In the absence of complete futures markets, ${ }^{7}$ any output decision, involving as it does investments in both working and fixed capital before output is sold, is inherently a risky investment decision. Consequently changes in the economy which either increase the risks associated with a given level of output or deplete the stock of firm equity (working) capital will be accompanied by a reduction in the level of output and investment. If firms tend to hold real assets and nominal liabilities (i.e. fixed nominal debt contracts), then shocks which lead either to a decrease in the general price level (money shocks) or the prices of good sold by each firm (relative demand shocks) will reduce the real equity levels of firms and, accordingly, reduce output and investment. Increased uncertainty about factor prices (e.g. "oil shocks"), relative price variations (associated, for example, with more rapid inflation) or the direction of public 
policy will also reduce output. And, government interventions (e.g. in labor markets) which reduce the flexibility of firms' responses to changing market conditions will have a similar effect. ${ }^{8}$

These increases in risk, relative to equity levels, increase the "risk premium" associated with any increase in output and hence reduce the "effective" or "risk adjusted" marginal product of labor. Thus, without relying on any artificial rigidities in prices, informational imperfections in capital markets can give rise to potentially large fluctuations in the "effective" marginal product of labor in response to changing conditions that in an economy with perfect markets would be absorbed with little or no impact on overall economic activity. Moreover an asymmetric distribution of information between borrowers and lenders may reinforce these basic effects (especially in response to monetary policy shifts) both as borrowers anticipate the possibility of having credit rationed in the future and as current credit constraints, by limiting working capital investments, effectively reduce the marginal product of labor. ${ }^{\circ}$

Assume for simplicity that the utility of a firm's decision-makers (whether owner-entrepreneurs or hired managers) is a function of end of period equity. Looking forward from the beginning of the period (when decisions are made), end-of-period equity is a random variable,

$$
\tilde{a}_{t}=\tilde{p}_{t} f\left(\ell_{t}\right)-w_{t} \ell_{t}+a_{t-1}
$$

where

$$
\begin{aligned}
& \tilde{p}_{t} \text { is the uncertain end-of-period price at which } \\
& \text { the firm's output will be sold, } \\
& \ell_{t} \quad \text { is the level of labor input, } \\
& f \quad \text { is a production function of the usual sort, } \\
& w_{t} \quad \text { is the wage paid to workers and } \\
& a_{t-1} \quad \text { is the beginning of period equity that the firm } \\
& \text { inherits from period } t-1 .
\end{aligned}
$$

With perfect capital markets, we would have to add new equity sales to the right-hand side of equation (1). However, as argued above, informational imperfections in capital markets will limit these sales and for simplicity we will assume that such equity sales are zero. ${ }^{10,11}$ Thus, equation (1) implicitly embodies the informational imperfections in the capital market.

We will assume formally that in making decisions at the beginning of period $t$, a frm's decision makers

$$
\max E\left[u\left(\tilde{a}_{t}\right)\right]
$$


where the utility function $u$ is characterized by decreasing absolute risk aversion.

The first order condition determining the optimal level of employment by a firm facing a wage $w_{t}$ is,

$$
E\left[\tilde{u}_{t}^{\prime} \cdot\left(\tilde{p}_{i} f^{\prime}-w_{i}\right)\right]=0 \text {. }
$$

Rearrangement of terms and use of the fact that $E\left[\tilde{u}_{i}^{\prime} \cdot \tilde{p}_{l}\right]=E\left[\tilde{u}_{i}^{\prime}\right] E\left[\tilde{p}_{i}\right]+\operatorname{Cov}\left[\tilde{u}_{i}^{\prime}, \tilde{p}_{l}\right]$ yields the result that

$$
f^{\prime}\left(\ell_{t}\right)\left(1+\operatorname{Cov}\left[\tilde{u}_{i}^{\prime} \cdot \tilde{p}_{t}\right]\right)=w_{t}
$$

where, by choosing suitable normalizations and units, $E\left[\tilde{u}_{t}^{\prime}\right]=E\left[\tilde{p}_{t}\right]=1$. On the left hand side of equation (3), the covariance of price levels and marginal utilities is negative as long as $u$ is characterized by aversion to risk in some degree. Thus, the impact of capital market imperfections is in general to reduce the risk-adjusted marginal product of labor and consequently employment. Moreover, after a negative demand shock (or moneta y disturbance) which impairs the equity base of a firm, $a_{t-1}$ will be reduced and, if $u$ is characterized by decreasing absolute risk aversion, the negative covariance term will increase in magnitude. If at the same time policy or other uncertainties increase the variance of the future price distribution, this effect will be reinforced and the demand for labor reduced further.

\section{Lay-offs}

In the context of long-term employment relationships, lay-offs from which workers return to their original employers are one kind of unemployment to which these fluctuations in demand may give rise. Assume that a firm has a labor force, $\bar{l}_{h}$, under long term contract at the beginning of period $t$ and that the marginal disutility of labor for these workers is $w_{0} \cdot{ }^{12}$ If the risk-adjusted marginal product of labor falls far enough so that

$$
f^{\prime}\left(\bar{\ell}_{\imath}\right)\left(1+\operatorname{Cov}\left[\bar{u}_{i}^{\prime} \cdot \tilde{p}_{i}\right]\right)<w_{0}
$$

then a firm offering long term contracts will find it optimal to lay-off workers. The temporary nature of these lay-offs, which would ensure that the workers involved not seek employment elsewhere, rests on the possibility that the firm will ultimately restore its equity level through the accumulation of retained earnings over time. As its equity base increases the "risk" of increased output will decline, the effective marginal product of labor will rise and laid-off workers will be called back. ${ }^{13}$ 
There are several possible senses in which these temporary lay-offs represent involuntary unemployment. Most familiarly, but perhaps least importantly, workers who look only at the average wages implied by their long term employment relationships would be willing to work at that average wage during the period they are laid off. They may not see that the average wage is calculated to smooth out temporary variations in the marginal product of labor and is not the appropriate standard for assessing incremental employment opportunities. A second more significant sense in which these temporary lay-offs are "involuntary" is that they represent a Pareto inefficiency. With an appropriate mechanism for spreading the risks associated with increased output and investment (or for circumventing credit rationing constraints), both firms and workers could profit from the employment of laid-off workers. If firms offered (and workers were willing to accept) equity shares in future output in lieu of current wages, then lay-offs could, in theory, be avoided. However, the firms willing to do this are likely to be those whose future equity values are low relative to their observable characteristics. And workers, just like outside equity investors, ought to avoid such offers. Thus, informational failures are as likely to interfere with employment contracts that distribute risk as they are with explicit financial market arrangements. ${ }^{14}$

\section{Cyclical Variations in Hiring}

In practice, many lay-offs do not lead to reemployment and durations of unemployment appear to increase significantly in recessionary times. Wage levels in markets for unemployed workers without any rehiring expectations from their most recent employers do not, therefore, appear to adjust quickly enough to clear those markets.

Capital market imperfections can however account for this variability in employment, when the jobs in question are primary sector jobs which involve substantial training costs and potential long term relationships between employers and workers. Assume as before that firms maximize a function, $u$, of their end of period equity position. Assume, in addition, that an existing stock of trained workers represents the only element of each firm's capital stock. Then the value of a firm's equity at the end of period $t$ is

$$
a_{t}-y_{i}+\tilde{v}_{1}
$$

where $a_{1}$ represents the beginning of period net liquid assets of the firm, $y_{t}$ is the present value of current and committed future expenditures on the existing labor force and $\bar{v}_{t}$ is a certainty equivalent at the end of period $t$ of the uncertain future net value from that time forward of the labor supplied by a firm's existing labor force. This last quantity is uncertain looking forward from the beginning of period $t$. Some price and productivity uncertainties will be resolved during the course of period $t$ and their resolution is 
reflected in the distribution of $\tilde{v}_{t}$. The remaining uncertainties looking forward from the end of period $t$ are subsumed in the process of taking the certainty equivalent. Here $y_{t}$ and $\tilde{v}_{t}$ are, of course, functions of employment.

The first-order condition governing the hiring of an additional worker at the beginning of period $t$ is that

$$
E\left[\tilde{u}^{\prime} \cdot\left(-\frac{d y_{t}}{d \ell_{t}}+\frac{d \bar{v}}{d \ell_{t}}\right)\right]=\mathbf{0}
$$

which, using the appropriate normalization $E\left[\tilde{u}^{\prime}\right]=1$, becomes

$$
\frac{d y_{t}}{d \ell_{t}}=E\left[\frac{d \tilde{v}_{t}}{d \ell_{t}}\right]+\operatorname{Cov}\left[\tilde{u}^{\prime}, \frac{d \tilde{v}}{d \ell_{t}}\right] .
$$

For simplicity we will assume that both the training costs borne by firms and the wages that they implicitly undertake to pay take the form of fixed payments promises at the time a worker is employed and that these have the same status as debt to the decision makers of the firm. ${ }^{15}$

If $y_{t}$ comprises total wages, then

$$
\frac{d y_{t}}{d \ell_{t}}=\sum_{i=0}^{\infty} w_{t+i} \delta_{j}+h_{t}
$$

where $w_{t+i}$ is the wage payment promised in period $t+i, \delta_{i}$ is an adjusted discount factor encompassing the effects of both the real rate of interest and the probability that a worker quits before period $i$ (i.e. $\delta_{i}=s_{i} \delta_{i}$ where $\bar{\delta}_{i}$ is a discount factor of the normal sort and $\delta_{i}$ is the probability that a worker remains with the firm through period $t+i)$ and $h_{4}$ is the out-of-pocket cost of hiring and training a worker.

Ignoring endogenous variations in the probability of continued employment, the term $d \bar{v}_{t} / d \ell_{t}$ is the end of period $t$ certainly equivalent of

$$
\sum_{i=0} \tilde{p}_{t+i} \cdot f^{\prime}\left(\tilde{\ell}_{t+i}\right) \delta_{t+i}
$$

where $\tilde{p}_{t+i}$ is the future level of prices, $f^{\prime}\left(\tilde{\ell}_{t+i}\right)$ is the future marginal product of labor and, assuming firms and workers have the same discount rates, $\delta_{t+i}$ is the adjusted discount factor defined above. Assuming that $u$ is characterized by decreasing absolute risk aversion, decreases in the initial liquid equity of firms (i.e. $a_{t-1}$ ) and increases in uncertainty concerning future prices and marginal productivities will reduce the value of the certainty equivalents that make up $d \tilde{v}_{t} / d \ell_{t}$, reducing $E\left(d \tilde{v}_{t} / d \ell_{t}\right)$. In addition as $a_{t-1}$ falls in 
response to negative demand or monetary shocks in period $t-1$, the magnitude of the $\operatorname{Cov}\left[\tilde{u}^{\prime} \cdot d \tilde{v}_{1} / d \ell_{1}\right]$, which is negative, will increase. For both reasons, therefore, the right-hand side of equation (5) will decline in a recession. The right-hand side of equation (5) evaluated at a firm's existing level of employment represents the marginal "value" to the firm from hiring an additional worker.

As firms accumulate equity over time, the right-hand side of equation (5) will rise and accordingly

$$
\frac{d y_{1+1}}{d \ell_{1+1}}=\sum_{i=0}^{\infty} w_{i+1+i} \delta_{i}+h_{t+1}>\frac{d y_{1}}{d \ell_{i}}=\sum_{i=0}^{\infty} w_{t+i} \delta_{i}+h_{t}
$$

If this gap is sufficiently large (because in the depths of a recession firms are sufficiently risk averse) so that, ignoring end effects (i.e. assuming workers are long lived relative to the length of a typical recession)

$$
\frac{d y_{t+1}}{d \ell_{t+1}}>\left(1+\tau_{t}\right) \frac{d y_{t}}{d \ell_{t}}
$$

where $r_{t}$ is an appropriate real interest rate for workers, then it is rational for workers to delay taking a long-term job until economic conditions improve. There are, in effect, no offers that firms would be willing to make in the depths of a recession that workers would be willing to accept.

The resulting "unemployment" is involuntary in the sense that, absent informational imperfections, there is a Pareto improving bargain that could be struck between workers and firms. It consists, as in the lay-off case discussed above, of workers agreeing to accept contingent equity-like wage offers and absorb a greater share of the risks associated with higher output. But since the firms likely to offer these contracts (e.g. Eastern Airlines) are just the firms from whom workers do not want to accept them, such arrangements are difficult to make. ${ }^{10}$

\section{Efficiency Wage Models}

The models we have discussed explain fluctuations in the demand curve for labor. They also explain why even with perfectly flexible wages, there may be lay-offs: at the wages which firms would be willing to keep their employees, the employees are not willing to work; and though firms would be willing to promise to pay workers in the future for current work, such promises are not credible, given the informational imperfections.

During the past ten years, a different strand of literature has focused on a different set of limitations on information and on contracting in the labor market as an explanation of wage rigidity and unemployment. This literature argues that for a variety of reasons (selection, incentive, morale, turnover) net 
productivity increases with wages, sufficiently so that it may not pay firms to lower their wage, even in the face of an excess supply of labor. ${ }^{17}$ These efficiency wage theories have been used to explain the existence of competitive market equilibria with unemployment. Some versions of the theory explain why wages may not change at all, in the face of a change in the demand for labor; ${ }^{18}$ while in other versions ${ }^{10}$ the real wage falls somewhat, but not enough to absorb the full impact of the variability in the demand for labor. Thus, in these models, the variability in the demand for labor arising from the capital market imperfections discussed in previous sections of this paper gives rise to variability in employment: the two theories are thus complementary. ${ }^{20}$

Capital market imperfections interact with efficiency wage theory in two other ways. First, many of the efficiency wage arguments would be mitigated if workers had sufficient capital to post oonds, ensuring their performance; but capital market imperfections mean that unless they have inherited or saved sufficient capital, they cannot post an adequate bond. Indeed, in many instances the employment relationship itself arises from differential ownership of or access to capital. ${ }^{21}$

Secondly, firms' responses to changes in environment are affected by their attitudes towards risk; and the kinds of capital market imperfections on which we focused in previous sections induce risk averse behavior on the part of many firms. Thus, consider a disturbance to the economy; and assume that firms believe that, as a result of efficiency wage considerations, productivity depends on relative wages. There is still some uncertainty about the effect of the disturbance on their workers' productivity, even were they to keep their relative wage fixed; but this uncertainty increases if they change the relative wage. They may believe that an increase (or decrease) in relative wages will increase profitability, but the increased uncertainty associated with such an action, combined with their risk aversion, induces them to keep wages fixed, thus precluding the kinds of responses which would facilitate the adjustment of the economy to the disturbance.

Efficiency wage theory has been particularly successful in explaining the pattern and form of unemployment, in explaining why there should be differential unemployment rates among different groups, in explaining why changes in the demand for labor should have differential effects on different groups, and in explaining why a reduction in the demand for labor should take the form of lay-offs rather than worksharing. It has not been able to explain why there should be fluctuations in the demand for labor (given that technology and capital stock seem to vary little in the short run). Our theory of capital market imperfections provides the missing link. For their part, efficiency wage theories are capable of explaining 
unemployment in secondary sectors of the economy and the existence of long-lived non-cyclical queues for primary sector jobs. Thus, they complete the full range of explanations of the various types of unemployment outlined in the introduction to this paper.

\section{Footnotes}

${ }^{1}$ This list of criticisms of the Keynesian model is not meant to be exhaustive. An early criticism was that Keynes' theory predicted that real wages should rise in recessions, contrary to what in fact occurred. Solow-Stiglitz [1968], Barro-Grossman [1976] and the subsequent fixed price literature resolved this difficulty by simply assuming that firms were off their supply curve. But the other criticisms leveled against the Keynesian model can also be leveled against most of the fixed price literature. Moreover, all of these models suffer from one central criticism: they simply leave unexplained why firms do not cut prices in order to sell more. Imperfect competition versions of these models do not provide a persuasive answer, for they must explain why the mark-up (the effective elasticity of demand) moves cyclically. (See Stiglitz [1984]).

${ }^{2}$ Several of the other explanations to be discussed in this session (such as the Insider-Outsider model) can also be viewed as complementary with the theory to be presented here.

${ }^{3}$ An important distinction here must be maintained between (1) theories of chronic unemployment of the kind that affects certain sectors and groups and seems to be increasingly characteristic of European labor markets and (2) theories of cyclical variations in unemployment that have been the traditional focus of macroeconomic concern with the "unemployment" problem. The incidence of these changes in unemployment rates differs markedly, e.g. across race, sector, and industry.

"Similarly, models which assume market clearing (flexible real wages) must explain either why preferences move cyclically, or why the marginal productivity schedule shifts. The recent work on real business cycles, attempting to attribute cyclical variations in employment to technology shocks, has been rightly criticized for being unable to identify events of sufficient importance that they could come anywhere near to explaining the observed variability in unemployment.

${ }^{5}$ See, for example, Arrow [1970], Wilson [1977], Rothschild-Stiglitz [1976] on insurance markets; Greenwald [1979], Stiglitz [1976] on labor markets; Jaffee and Russell [1976], Stiglitz-Weiss [1981] and Ross [1977] on financial markets and Akerlof [1970] for a general discussion of the adverse selection issue.

- For formal models of this phenomenon see Greenwald, Stiglitz and Weiss [1984], Majluf and Myers [1984] and, in a slightly different spirit, Leland and Pyle [1977]. In fact, equity issue announcements are accompanied by significant declines in stock prices of the issuing company (see Asquith and Mullins [1983]) and this is presumably related to the observation that internally generated funds are by far the predominant source of equity for most firms (see Taggart [1983]).

${ }^{7}$ The non-existence of many futures markets may also arise from imperfect information concerning the quality and reliability of delivery on all but the simplest contracts.

${ }^{8}$ For a formal general equilibrium macroeconomic model of these phenomena see Greenwald-Stiglitz [1986].

${ }^{9}$ See Stiglitz-Weiss [1981].

${ }^{10} \mathrm{~A}$ model having firms' managers being averse to the risk of bankruptcy but otherwise risk neutral produces results which are essentially similar to the generalized risk aversion assumed here. See Greenwald-Stiglitz [1986] which includes a justification (to the extent it is necessary) for having utility depend upon end of period equity.

${ }^{11}$ Dividends can be viewed as negative equity issues. Standard signalling arguments explain why firms may be reluctant to adjust dividends in the face of changes in economic circumstances, and why 
accordingly the dividend rates may, in the short run, be taken as fixed. Our model can be extended to include the endogenous determination of the dividend level; this would complicate the analysis without changing the basic conclusions.

${ }^{12}$ Since lifetime income depends on long term wages $w_{0}$ should not vary with short term conditions. The argument here is essentially that presented by Baily [1977], reinforced at critical points by the impact of informational imperfections.

${ }^{13}$ Note that in this analysis, we have assumed complete flexibility in the (shadow) wage paid workers in the long term contract.

${ }^{14}$ There remains the problem of why workers do not seek interim employment with other firms. There are several reasons for this. First, since such employment is likely to be relatively short-lived it does not pay to expend much effort searching for such jobs. Second, alternative employment in a laid-off worker's speciality may not be available if similar firms are subject to the same "shocks". Third, accepting and then quitting an interim job may involve substantial informational costs for a worker. Acceptance of a "low-paying" alternative job may be taken as evidence that the worker has doubts about his own abilities and/or his chances of rehiring by his original employer. If workers are better informed about their own abilities than the market at large this "negative" signal may reduce their future earnings. Also, if a temporary employer observes a worker's ability and does not attempt to prevent his return to his original employer, this too may constitute a "negative" signal with adverse consequences for future earnings (see Greenwald [1986]).. Notice that the latter arguments again reflect imperfect information.

15 In practice, such fixed commitments make up only part of future wages with the remaining part dependent on the future productivity of workers. This could be easily accommodated within the framework outlined above by having $y_{t}$ represent only the fixed commitment portion of wages and $\tilde{v}_{t}$ be net of the contingent portion of wages. The important constraint in what follows is that the mix of fixed to contingent labor costs not be freely variable. The informational argument in support of this kind of constraint is similar to that supporting the no equity constraint. Firms that deviate from common practice by requiring that workers pay for hiring and training costs and by offering wages that are heavily weighted toward contingent payments (essentially equity in the firm) are disproportionately likely to be weak firms or firms who are prone not to fulfill contingent promises. In either case workers are presumably likely to avoid such firms.

${ }^{10}$ Two final remarks ought to be made about this kind of unemployment. First, in contrast to many models of cyclical unemployment, it arises precisely because workers recognize that they are in a recession, not because they are unable to distinguish between local and economy wide conditions. Second, the reason workers do not accept jobs and quit for new ones when conditions improve must depend on the informational cost (stigma) attached to such behavior discussed above. If this were not the case, then such behavior would itself deter hiring by firms since $\delta_{i}$ would now be small, reducing $d \tilde{v}_{t} / d \ell_{t}$ and wages but not $h_{t}$.

${ }^{17}$ See Yellen [1984] or Stiglitz [1987] for a survey of these models.

${ }^{18}$ See Stiglitz [1985].

${ }^{10}$ See Shapiro-Stiglitz [1984].

${ }^{20}$ Other versions of the efficiency wage theory give less clear cyclical predictions. Thus, in the selection version, if the reservation (self-employment) wage falls in a recession, the primary sector wage may fall more or less proportionately.

Also, there has been some concern about the consistency of observed patterns of cyclical movements in productivity and wages with the effort-efficiency wage model. The threat of unemployment should presumably induce retained workers to work even harder in recessionary periods, yet productivity typically declines. As we have argued, however, in the primary sector workers have long term relationships, and the incentive to work is provided by the long term relationships, and the value of this is enhanced by some wage/employment smoothing.

${ }^{21}$ That is, self-employment obviates many of the sources of the efficiency wage problem. 
Bibliography

Akerlof, G. [1970], "The Market for Lemons: Qualitative Uncertainty and the Market Mechanism", $Q u a r-$ terly Journal of Economics, Vol. 84, pp. 288-300.

Arrow, K. J. [1970], Essays in the Theory of Risk Bearing, North-Holland, London.

Asquith, P. and Mullins, D. W. [1983], "Equity Issues and Stock Price Dilution", unpublished paper, Harvard Business School.

Baily, M. N. [1977], "On the Theory of Lay-Offs and Unemployment", Econometrica, Vol. 45, pp. $1043-61$. Barrow, R. and Grossman, H. [1976], Money, Employment and Inflation, Cambridge Univ. Press, Cam-
bridge.

Greenwald, B. [1979], Adverse Selection in the Labor Market, Garland Press, New York.

Greenwald, B. and Stiglitz, J. E. [1986], "Information, Finance Constraints and Business Fluctuations", unpublished paper, Bell Communications Research.

Greenwald, B., Stiglitz, J. E. and Weiss, A. [1984], "Informational Imperfections and Macroeconomic Fluctuations", American Economic Review, Papers and Proceedings, Vol. 74, pp. 194-199.

Grossman, S. J., Hart, O. D. and Maskin, E. S. [1983], "Unemployment with Observable Aggregate Shocks", Journal of Political Economy, Vol. 91, pp. 907-928.

Jaffee, D. and Russell, T. [1976], "Imperfect Information and Credit Rationing", Quarterly Journal of Economics, Vol. 90, pp.651-66.

Leland, H. E. and Pyle, D. H. [1977], "Informational Asymmetries, Financial Structure, and Financial Intermediation", Journal of Finance, Vol. 32, pp. 371-87.

Myers, S. C. and Majluf, N. S. [1984], "Corporate Financing and Investment Decisions When Firms Have Information that Investors Do Not", Journal of Financial Economics, Vol. 11, pp. 187-221.

Malinvaud, E. [1977], The Theory of Unemployment Reconsidered, Blackwell, Oxford.

Ross, S. A. [1977], "The Determination of Finance Structure: The Incentive Signalling Approach", Bell Journal of Economics, Vol. 8, pp. 23-40.

Rothschild, M. and Stiglitz, J. E. [1976], "Equilibrium in Competitive Insurance Markets: An Essay on the Economics of Imperfect Information", Quarterly Journal of Economics, Vol. 90, pp. 629-50.

Salop, S. [1979], "A Model of the Natural Rate of Unemployment", American Economic Review, Vol. 69, pp. 117-125.

Shapiro, C. and Stiglitz, J. E. [1984], "Equilibrium Unemployment as a Worker Discipline Device", American Economic Review, Vol. 74, pp. 433-444.

Solow, R. and Stiglitz, J. E. [1968], "Output, Employment and Wages in the Short Run", Quarterly Journal of Economics, Vol. 82, pp. 537-60.

Stiglitz, J. E. [1974], "Wage Determination and Unemployment in LDC's: The Labor Turnover Model", Quarterly Journal of Economics, Vol. 88, pp. 194-227.

Stiglitz, J. E. [1976], "The Efficiency Wage Hypothesis, Surplus Labour, and the Distribution of Income in LDC's", Oxford Economic Papers, Vol. 28, pp. 185-207.

Stiglitz, J. E. [1985], "Equilibrium Wage Distributions", Economic Journal, Vol. 95, pp. 595-618. 
Stiglitz, J. E. [1987], "The Causes and Consequences of the Dependence of Quality on Price", Journal of Economic Literature, Forthcoming.

Stiglitz, J. E. and Weiss, A. M. [1981], "Credit Rationing in Markets with Imperfect Information", American Economic Review, Vol. 71, pp. 393-410.

Taggart, R. A. [1983], "Secular Patterns in Financing U.S. Corporations", unpublished paper, Harvard University.

Wilson, C. A. [1977], "A Model of Insurance Markets with Incomplete Information", Journal of Economic Theory, Vol. 14, pp. 167-207.

Yellen, J. [1984], "Efficiency Wage Models of Unemployment", American Economic Review, Papers and Proceedings, Vol. 74, pp. 200-205. 